http://jurnal.stmikroyal.ac.id/index.php/jurdimas

\title{
MELIRIK HIDROPONIK SAYURAN SEGAR SKALA RUMAH TANGGA SEBAGAI PELUANG USAHA
}

\author{
Hommy D. E. Sinaga ${ }^{*}$, Novica Irawati ${ }^{1}$ \\ ${ }^{1}$ Program Studi Sistem Informasi, STMIK Royal Kisaran \\ Email : omisinaga@royal.ac.id
}

\begin{abstract}
This community service is provided to wives of civil servants called Darma Wanita at RSUD HAMS Kisaran, in creating positive activities at their homes and they also could get knowledge to be an entrepreneur through the activities. The community service is delivered in workshop and training method how to plant the vegetables such as water spinach (aka kangkung) in hydroponic wick system. The expected return is the wives could plant this hydroponic water spinach at their own yard so they can produce fresh and healthy Water Spinach for their family and they also can get additional income through the sales of the vegetables.
\end{abstract}

Keywords: Entrepreneurship, Hydroponic, Wick system, Wives of civil servants,

Abstrak:Pengabdian masyarakat ini ditujukan kepada kelompok Ibu-ibu Darma Wanita Persatuan UP RSUD HAMS Kisaran, dimana selaku pendamping suami yang bertugas sebagai ASN (Aparatur Sipil Negara), para istri dapat melakukan kegiatan yang positif sekaligus menjadi peluang usaha dalam skala rumah tangga. Kegiatan pengabdian masyarakat yang dilakukan adalah memberikan informasi dan pelatihan menanam sayuran kangkung secara hidroponik sederhana dengan sistem sumbu (Wick System). Diharapkan nantinya, dengan bekal pengetahuan ini, para istri dapat melakukannya di rumah masing-masing dan nantinya akan dapat dengan mudah menyediakan sayuran segar dan bebas pestisida bagi keluarganya, sekalipun pada area pekarangan yang terbatas, dan sekaligus dapat pula dijadikan peluang usaha untuk menambah pendapatan keluarga.

Keywords: darma wanita, hidroponik, peluang usaha, sistem sumbu

\section{PENDAHULUAN}

Menurut hasil survei BPS (2001), konsumsi sayuran di Indonesia meningkat dari $31,790 \mathrm{~kg}$ pada tahun 1996 menjadi 44,408 kg per kapita per tahun pada tahun 1999. Hasil survei tersebut juga menyatakan bahwa semakin tinggi pengeluaran konsumen, semakin tinggi pengeluaran untuk sayuran per bulannya dan semakin mahal harga rata-rata sayuran per kilogramnya yang mampu dibeli oleh konsumen.Artinya bahwa selain kuantitas, permintaan sayuran juga meningkat secara kualitas.Hal ini membuka peluang pasar terhadap peningkatan produksi sayuran, baik secara kuantitas maupun kualitas.Namun di lain pihak, pengembangan komoditas sayuran secara kuantitas dan kualitas dihadapkan pada semakin sempitnya lahan pertanian yang subur, terutama di Pulau Jawa.Sampai saat ini, kebutuhan konsumen terhadap sayuran yang 
http://jurnal.stmikroyal.ac.id/index.php/jurdimas

berkualitas tinggi belum dapat dipenuhi dari sistem pertanian konvensional.

Hidroponik, adalah bercocok tanam tanpa menggunakan tanah, mengandalkan air sebagai medianya.Sistem hidroponik ini mulai menjadi terkenal mulai tahun 1990an.

Dengan semakin terbatasnya lahan pertanian di perkotaan, adanya keinginan untuk memastikan sayuran segar yang akan dikonsumsi bebas pestisida maka menanam sayuran dengan sistem hidroponik dapat menjadi salah satu alternatif solusi bagi masyarakat. Apalagi metode penanaman hidroponik ini dapat memanfaatkan barang bekas sehingga dapat menekan biaya produksi.

Dari keterbatasan dalam menjalani peran sebagai pendamping suami, maka bercocok tanam secara hidroponik dapat menjadi satu kegiatan yang positif bagi Ibu Rumah Tangga (IRT) yang tergabung dalam organisasi Dharma Wanita dimana kegiatan ini dapat dilakukan di rumah masing-masing, sehingga IRT pun dapat dengan mudah menyediakan sayuran segar bebas pestisida bagi keluarganya sekalipun pada area pekarangan yang terbatas.

Bagi IRT yang ingin melakukan suatu usaha, maka dari berhidroponik ini pun dapat diciptakan usaha yang menghasilkan dan sangat memungkinkan dilakukan tanpa harus meninggalkan rumah dengan memanfaatkan barang bekas.

\section{METODE}

\section{Materi Pengabdian Masyarakat}

Materi pokok Pengabdian

Masyarakat adalah:

1. Pengenalan jenis-jenis hidroponik. Peserta diajarkan mengenali jenis-jenis sistem hidroponik, istilah-istilah dan perlengkapan berhidroponik.

2. Pengenalan cara menyemai, membesarkan dan pemberian nutrisi hidroponik terhadap tanaman sayur.

3. Peluang usaha menanam sayuran dengan metode hidroponik skala rumah tangga. Peserta diajak menghitung biaya dan laba menanam sayur kangkung dengan cara hidroponik system sumbu.

4. Praktek menanam sayur kangkung secara hidroponik menggunakan botol air mineral bekas.

\section{Metode Pengabdian Masyarakat}

Metode yang dilakukan dalam pengabdian masyarakat ini dengan cara ceramah, penyampaian secara teoritis terkait materi yang dibahas dan pelatihan praktek langsung menanam sayuran kangkung dari benih menggunakan botol bekas.

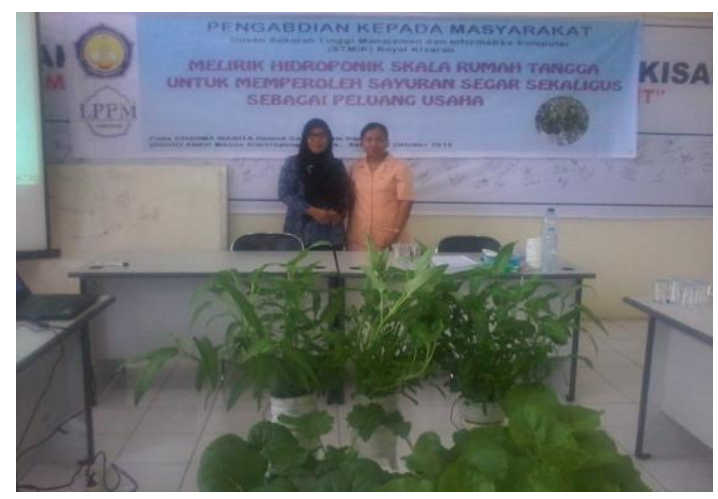

Gambar 5 Tim pengabdian masyarakat 
http://jurnal.stmikroyal.ac.id/index.php/jurdimas

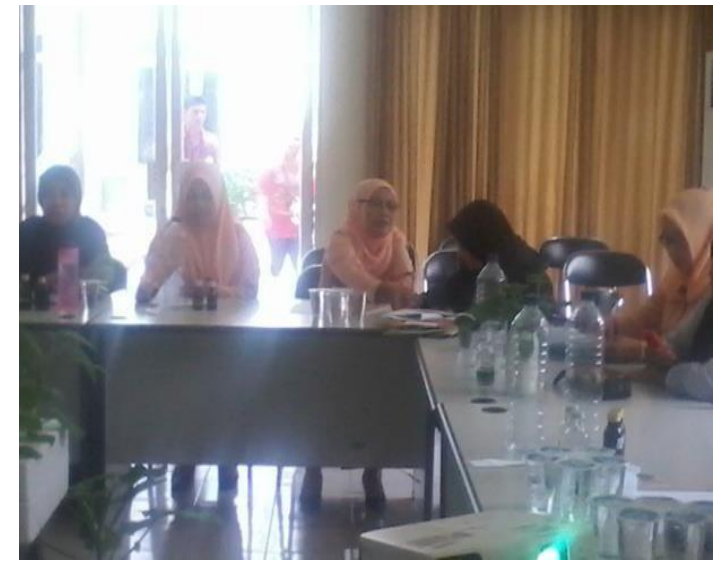

Gambar 6 Peserta pengabdian masyarakat

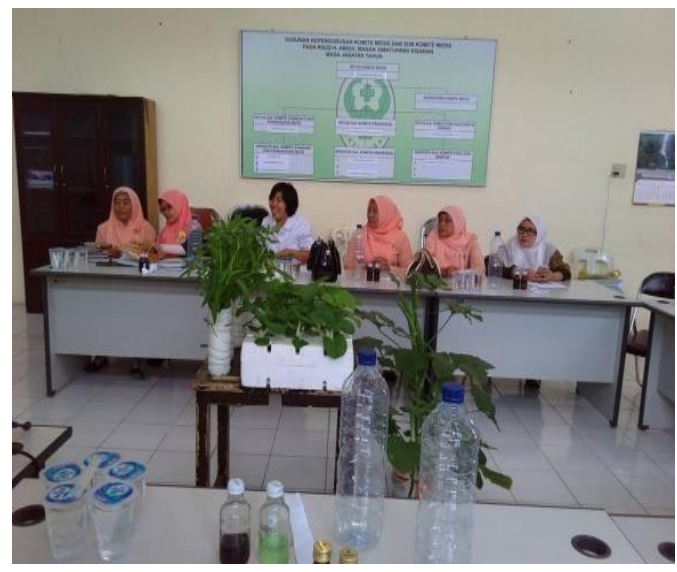

Gambar 7 Sesi ceramah

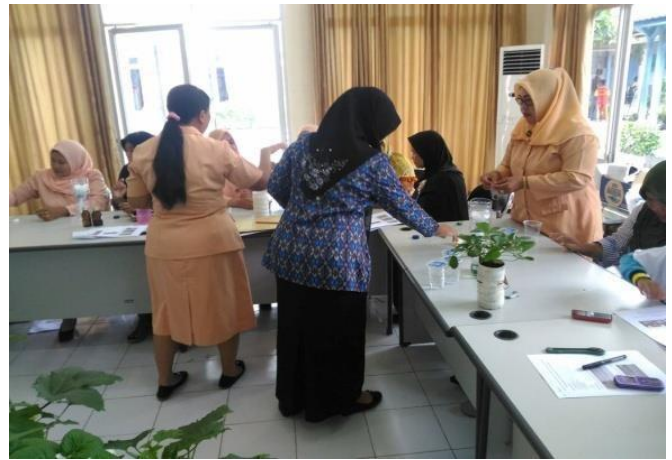

Gambar 8 Penjelasan bahan dan alat yang digunakan

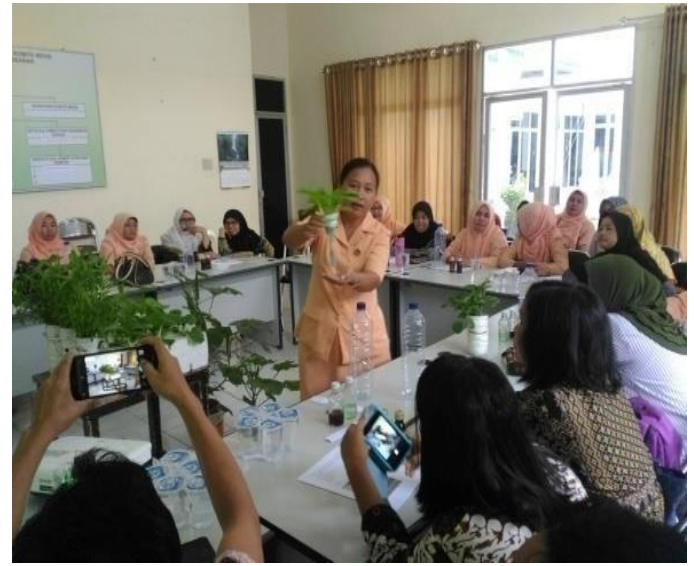

Gambar 9 Praktek penanaman kangkung hidroponik

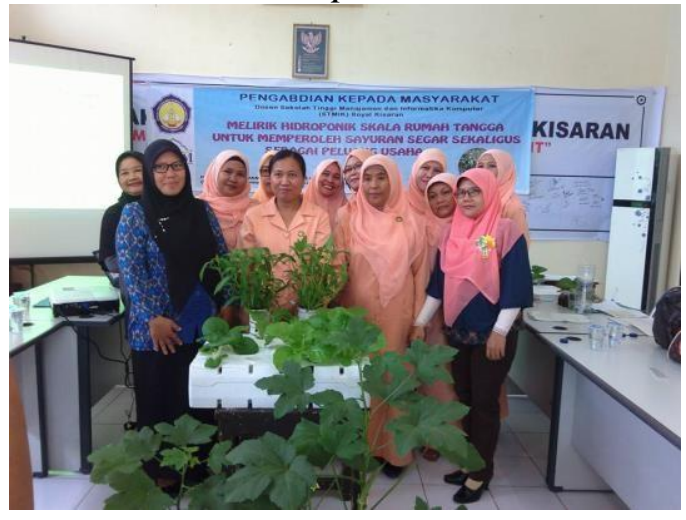

Gambar 10 Foto bersama

\section{PEMBAHASAN}

Sebagai salah satu perwujudan pelaksanaan Tri Darma Perguruan Tinggi maka pada hari Sabtu tanggal 22 Oktober 2016 telah dilaksanakan kegiatan pengabdian masyarakat yang sebelumnya sudah direncanakan oleh tim dosen STMIK Royal Kisaran pada Dharma Wanita RSUD HAMS Kisaran dengan tema "Melirik hidroponik skala rumah tangga untuk memperoleh sayuran segar sekaligus sebagai peluang usaha".

Jumlah peserta pelatihan terdiri dari 19 orang Ibu Dharma Wanita dan 4 orang 
Jurdimas (Jurnal Pengabdian Kepada Masyarakat)

Vol. I No. 1, Januari 2018, hlm. 29 - 33

Available online at

http://jurnal.stmikroyal.ac.id/index.php/jurdimas

undangan khusus dari luar Dharma Wanita yang berminat untuk belajar hidroponik. Dimana kegiatan pengabdian masyarakat ini dilaksanakan di Ruang Komite Medis RSUD HAMS Kisaran.

Adapun Tim dosen yang terlibat dalam kegiatan pelatihan terdiri dari 2 (dua) orang, yaitu:

1. Hommy Dorthy Ellyany Sinaga

2. Novica Irawati

Peserta dibagi menjadi 10 kelompok dan untuk tiap-tiap kelompok disediakan perlengkapan praktek menanam sebagai berikut:

- 1 (satu) botol air mineral bekas ukuran 1 liter

- 1 (satu) sachet benih kangkung berisi sekitar 20-30 butir benih

- 2 (dua) buah botol berisi nutrisi hidroponik AB Mix

- 1(satu) buah kain flannel berukuran $3 \times 25 \mathrm{~cm}$

- 2 lembar tissue

Kegiatan pengabdian masyarakat juga menggunakan 1 (satu) buah laptop pribadi dan 1 (satu) buah proyektor yang dipinjamkan dari RSUD dan acara ini dimulai dari pukul 09.00 - 15.00 WIB, berjalan lancar dan sukses.

Hasil dari kegiatan pengabdian masyarakat yang telah dilakukan oleh Tim dosen pengabdian masyarakat pada peserta adalah sebagai berikut:

1. Peserta mengerti dan memahami apa itu hidroponik dan mengapa perlunya bercocok tanam sayuran secara hidroponik.

2. Peserta mengetahui jenis-jenis sistem hidroponik.

3. Peserta memahami dan menyadari bahwa menanam sayuran dengan
ISSN 2614-7912 (Print)

ISSN 2622-3813 (Online) cara hidroponik adalah merupakan salah satu peluang usaha bagi Ibu Rumah Tangga.

4. Peserta sudah mampu menanam kangkung secara hidroponik dari benih dengan cara hidroponik.

5. Diluar tujuan utama kegiatan pengabdian masyarakat, terjalin komunikasi dan hubungan baik antara Dharma wanita RSUD HAMS Ksiaran dengan Tim dosen pengabdian masyarakat STMIK Royal Kisaran.

\section{SIMPULAN}

Adapun kegiatan pengabdian masyarakat ini dapat disimpulkan sebagai berikut:

1. Tema kegiatan pengabdian masyarakat yang dilakukan oleh Tim dosen STMIK Royal Kisaran pada Dharma Wanita RSUD HAMS Kisaran adalah "Melirik hidroponik skala rumah tangga untuk memperoleh sayuran segar sekaligus sebagai peluang usaha" dimana tugas ini merupakan pelaksanaan salah satu dari Tri Dharma perguruan tinggi yaitu pengabdian masyarakat dan akan memberi manfaat kepada dosen-dosen STMIK Royal Kisaran untuk mendapatkan kemudahan dalam mendapatkan jabatan fungsional.

2. Kegiatan ini dapat memberi pengetahuan kepada Ibu-ibu Dharma Wanita tentang ilmu menanam modern yaitu menanam sayuran secara hidroponik dan peluang usaha bagi para Ibu-ibu yang bisa dikerjakan melalui hidroponik skala Rumah 
http://jurnal.stmikroyal.ac.id/index.php/jurdimas

tangga untuk mendapatkan tambahan pendapatan bagi keluarga.

3. Kegiatan ini dapat menjalin hubungan baik antara STMIK Royal Kisaran dengan Dharma Wanita RSUD HAMS Kisaran baik di masa sekarang dan juga di masa yang akan datang.

4. Bentuk kegiatan pengabdian masyarakat yang dilakukan adalah memberikan pelatihan dan pengalaman belajar tentang menanam sayuran secara hidroponik dan peluang usahanya serta menanam sayuran kangkung skala rumah tangga dengan pemanfaatan botol bekas.

\section{DAFTAR PUSTAKA}

\section{Buku}

Parks, Sophie, 2011, Leafy Asian Vegetables and their nutrition in hydroponics, Industry \& Investment NSW, Orange

Roberto, Keith, 2003, How to hydroponics, $4^{\text {th }}$ edition, The Futuregarden Press, New York. Rosliani, Rini dan Nani Sumarni,2005, Budidaya tanaman sayuran dengan system hidroponik, Bandung, Balai Penelitian Tanaman Sayuran, Pusat Penelitian Pengembangan Hortikultura Badan Penelitian dan Pengembangan Pertanian.

\section{Jurnal Ilmiah}

Sardare, Mamta D. Admane, Shraddha V., 2013, A Review On Plant Without Soil Hydroponics, IJRET Volume 2, Issue 3, 299-304

\section{Artikel umum}

Hidroponik Sistem, 16 Agustus 2014, Cara Kerja Sistem Hidroponik, dikutip tanggal 14 Oktober 2016 dari https://hidroponiksistem.wordpress.com/ 